\title{
Intervention for executive functions in attention deficit and hyperactivity disorder
}

\author{
Intervenção para funções executivas no transtorno do déficit de atenção e hiperatividade \\ Amanda Menezes ${ }^{1}$, Natália Martins Dias², Bruna Tonietti Trevisan', Luiz Renato R. Carreiro', \\ Alessandra Gotuzo Seabra ${ }^{1}$
}

\begin{abstract}
This study aimed to investigate if an executive functions (EF) intervention could promote these skills in individuals with attention deficit and hyperactivity disorder (ADHD). Eighteen children and adolescents, 7-13 years old, divided into experimental (EG, $N=8)$ and control (CG, $N=10$ ) groups, were assessed in the Block Design and Vocabulary subtests of the WISC III and seven tests of EF. Parents answered two scales, measuring EF and inattention and hyperactivity signs. EG children participated in a program to promote EF in twice-weekly group sessions of one hour each. After 8 months of intervention, groups were assessed again. ANCOVA, controlling for age, intelligence quotient and pretest performance, revealed gains in attention/inhibition and auditory working memory measures for the EG. No effect was found for scales or measures of more complex EF. Results are not conclusive, but they illustrate some promising data about EF interventions in children and adolescents with ADHD.
\end{abstract}

Keywords: regulation, intervention, executive function, inattention.

RESUMO

Este estudo investigou se uma intervenção para funções executivas (FE) pode promover essas habilidades em indivíduos com transtorno do déficit de atenção e hiperatividade (TDAH). Participaram 18 crianças e adolescentes, 7-13 anos, divididos em Grupo Experimental (GE, N = 8) e Controle (GC, $N=10$ ), avaliados nos subtestes Blocos e Vocabulário do WISC III e sete testes de FE. Pais responderam a duas escalas mensurando FE e sintomas de desatenção e hiperatividade. As crianças do GE participaram de um programa de promoção de FE, em sessões de grupo de uma hora cada, duas vezes por semana. Após intervenção de oito meses, os grupos foram reavaliados. ANCOVA, controlando idade, QI e desempenho no pré-teste, revelou ganhos da intervenção em medidas de atenção/inibição e memória de trabalho auditiva para o GE. Nenhum efeito foi encontrado para as escalas ou medidas de FE mais complexas. Os resultados não são conclusivos, mas ilustram tendências promissoras sobre intervenções em FE em crianças e adolescentes com TDAH.

Palavras-chave: regulação, intervenção, função executiva, desatenção.

Attention deficit hyperactivity disorder (ADHD) is a developmental disorder that tends to persist for many years or entire lives. It is characterized as a persistent pattern of inattention and/or hyperactivity/impulsivity that is more frequent and severe than is typically observed in individuals at a comparable level of development ${ }^{1}$. Studies have sought to understand possible impairments associated with ADHD symptoms, which can be useful for the diagnosis of the disorder and for rehabilitation of deficit areas. In this sense, important neuropsychological processes have been implicated in $\mathrm{ADHD}$, including executive functions $(\mathrm{EF})^{2}$.

$\mathrm{EF}$ are responsible for top-down control of cognition, behaviors, and emotions. Core EF include inhibition (the ability to control an automatic or prepotent response and to control one's attention and thoughts), flexibility (the capacity to change the focus of attention and take different perspectives), and working memory (the capacity to keep and manipulate information in one's mind). Complex EF include skills such as planning, reasoning, and problem solving. $\mathrm{EF}$ are crucial to learning and appropriate functioning in society ${ }^{3}$.

Deficits in EF are one of the components of the complex neuropsychology of ADHD. Studies have reported significant deficits on measures of $\mathrm{EF}^{2,4}$; among them, the associations between $\mathrm{ADHD}$ and deficits in inhibitory control constitute the most consistent finding ${ }^{5}$. However, deficits in EF should

${ }^{1}$ Universidade Presbiteriana Mackenzie, Sao Paulo SP, Brazil;

${ }^{2}$ Centro Universitário FIEO, Osasco SP, Brazil.

Correspondence: Natália M. Dias; Centro Universitário FIEO; Programa de Pós-Graduação Stricto Sensu - Psicologia Educacional; Avenida Franz Voegeli, 300 / Bloco Prata (1 andar), Parque Continental; 06020-190 Osasco SP, Brasil; E-mail: natalia.dias@unifieo.br

Conflict of interest: There is no conflict of interest to declare.

Received 29 April 2014; Received in final form 29 October 2014; Accepted 17 November 2014. 
not be considered as a causal factor of the disorder. Some authors ${ }^{6}$ have reported that only $30 \%$ to $50 \%$ of children diagnosed with $\mathrm{ADHD}$ have $\mathrm{EF}$ deficits. Other evidence also found no correlation between ADHD and EF deficits?

In this sense, an important meta-analysis ${ }^{2}$ validated the importance of the EF in ADHD. The authors found that ADHD presented difficulties particularly in working memory, inhibition, monitoring, and planning. However, results also suggest that EF deficits are neither needed nor the cause of all cases of $\mathrm{ADHD}$, despite the fact that $\mathrm{EF}$ deficits are, in general, an important component of the neuropsychology of ADHD.

Despite the discussion on the role of EF in ADHD, the overall impairment of the disorder has been most evident when associated with EF disorders ${ }^{2,8}$. Some EF difficulties reported by ADHD patients are problems with deadlines and financial life, instability of motivation, difficultly regulating emotions, losing enthusiasm, not completing tasks, low frustration tolerance, and lack of self-monitoring - in addition to difficulties with taking initiative and starting tasks, inhibiting stimuli, planning, organizing and establishing priorities, setting goals, and time management ${ }^{9}$.

Although pharmacological treatment in ADHD has proved effective ${ }^{10}$, some specific interventions could be planned to address specific EF deficits. These could be implemented in support of the pharmacological treatment and could help improve day-to-day patient functioning. Some approaches have been used with positive results in ADHD interventions, such as cognitive-behavioral therapy and coaching ${ }^{11}$, behavioral interventions in clinical (including parent training) and school contexts ${ }^{12,13}$ or interventions to promote attention skills, such as the Pay Attention! program $^{14}$. Evidence has suggested that by promoting improvements not only of symptoms but also of the individual's functioning, such multimodal treatments (pharmacological and psychosocial) should be preferred to pharmacological treatment alone ${ }^{15}$. In this sense, psychosocial approaches have proven effective. Another line of research is the development and investigation of specific EF interventions. Instead of cognitive training, for which there are controversies about generalization of gains to other abilities ${ }^{16}$, this paper focuses on ecological EF intervention. The results of ecological approaches seem more generalizable, at least in children with typical development ${ }^{3}$.

Recent research suggests that it is possible to promote the development of EF in children and adolescents through specific activities ${ }^{17,18}$. For some authors, an improvement in $\mathrm{EF}$ in $\mathrm{ADHD}$ children could help to decrease impulsive responses and increase attention and memory, promoting better self-control and emotional regulation ${ }^{17}$. A recent Brazilian study ${ }^{19}$ found EF gains in typical six-year-olds after a one-year intervention. Gains were also evidenced in functional measures of $\mathrm{EF}$ and behavioral skills - maybe the same could happen with ADHD children using an ecological EF intervention. Thus, this study aimed to investigate if an ecological intervention for $\mathrm{EF}$ can promote $\mathrm{EF}$ gains in older children, students from elementary school, with ADHD.

\section{METHOD}

\section{Participants}

Recruitment was conducted in Sao Paulo by professionals and institutions specializing in the assessment and treatment of ADHD. Participants had confirmation of the diagnosis made by a neurologist, psychiatrist, or neuropediatrician. Data are reported on 18 children and adolescents (8 in the Experimental Group [EG] and 10 in the Control Group [CG]). Table 1 presents the subjects' descriptions. The criteria for inclusion of potential subjects were: (1) the diagnosis of ADHD; (2) attendance of a regular school; (3) chronological age between 7 and 17 years; and (4) non-use of any medication that might interfere with cognitive/emotional behaviors (except methylphenidate). The exclusion criteria were: (1) attendance of a special class (no participants

Table 1. Sample description with Control (CG) and Experimental Group (EG) data.

\begin{tabular}{|c|c|c|c|c|c|c|c|c|c|}
\hline \multicolumn{5}{|c|}{ Control Group } & \multicolumn{5}{|c|}{ Experimental Group } \\
\hline Gender & Age & Grade & School & Methylphenidate & Gender & Age & Grade & School & Methylphenidate \\
\hline M & 10 & 4 & Private & Yes & M & 13 & 8 & Public & Yes \\
\hline M & 13 & 7 & Private & No & M & 8 & 4 & Private & Yes \\
\hline M & 11 & 6 & Public & No & $\mathrm{F}$ & 10 & 5 & Private & No \\
\hline M & 10 & 3 & Public & No & M & 8 & 4 & Public & No \\
\hline $\mathrm{F}$ & 8 & 2 & Public & No & M & 10 & 5 & Private & No \\
\hline M & 8 & 2 & Public & No & $F$ & 10 & 6 & Private & Yes \\
\hline M & 7 & 2 & Public & No & M & 10 & 6 & Private & No \\
\hline M & 10 & 5 & Public & Yes & M & 8 & 3 & Private & No \\
\hline M & 13 & 7 & Public & Yes & & & & & \\
\hline M & 13 & 6 & Public & Yes & & & & & \\
\hline
\end{tabular}


were excluded based on this criterion); and (2) presence of comorbidities (according to parents' reports in the anamnesis interview).

The constitution of the experimental (EG) and control groups (CG) was for convenience sake (i.e., availability for participating in intervention meetings). Due to the sample size, the medication use (Methylphenidate) were not considered in the selection of participants, the division of the groups or analysis of the results. The level of intelligence was not considered as an exclusion criterion, but it was measured with the estimated intelligence quotient (IQ) of the WISC-III and was controlled statistically using analysis of covariance (ANCOVA).

\section{Instruments}

An Anamnesis interview was completed by the mothers of the participants to obtain more information about family and educational history, in addition to any complaints and possible treatments performed for the subjects.

The Computerized Stroop Test (Stroop-Comp) ${ }^{20}$ measures selective attention and inhibitory control. The part 1 assesses reading ability; in part 2, participants must name the color (yellow, blue, green, and red) of circles on a screen; in part 3, they must name the color of the colored written words (all in a incongruent situation, e.g., the word "green" is written in blue). We used score and reaction time (RT) in the second and third parts, and measured interference effects (performance in part 3 minus performance in part 2) for scores and RTs (the greater the interference effect for RT and the lower the effect for score, the more susceptible the performance is to interference). Validity evidence was reported for a Brazilian sample ${ }^{21}$.

The Cancellation Attention Test (CAT) ${ }^{22}$ assesses attention in a visual search test. The test consists of three parts. In each one the participant should identify and cancel the stimuli similar to the target in a matrix of 300 stimuli. There is a fixed time (one minute) for each matrix. We used the total number of hits as the score. Validity evidence can be found in Dias et al. ${ }^{21}$.

The Trail Making Test (TMT) $)^{22}$ assesses cognitive flexibility. Participants must connect numbers and letters in sequence, but alternately, in a one-minute period. We used sequences (number of items connected correctly) as the score. Validity evidence was reported by Dias et $\mathrm{al}^{21}$.

The Wisconsin Card Sorting Test (WCST) ${ }^{23}$ measures EF, such as cognitive flexibility, inhibitory control, working memory and monitoring. It consists of two identical decks with 64 cards each and four stimuli-cards. The cards vary in three dimensions: color, shape, and number. Participant must match each card from the deck to one of the four stimuli-cards. The proctor only informs if the classification is correct or wrong. After 10 consecutive correct responses, the sorting rule is changed without advising the subject. In this study, only one deck with 64 cards was used. We used the scores for number of hits, number of errors, perseverative responses, perseverative errors, failure to maintain set, and number of completed categories.

The Auditory Working Memory Test (AWM) ${ }^{24}$ is a computerized test and evaluates auditory working memory. The software emits sequences that consist of two to ten words and numbers. The task is to first repeat the words in the sequence, and then the numbers in increasing order. The score was the number of correct sequences. Validity evidence was reported by Dias et al. ${ }^{21}$.

The Visual Working Memory Test (VWM ${ }^{24}$ is a computerized test that assesses visual working memory. On the computer screen, one $3 \times 3$ matrix is shown, and it contains a stimulus (a geometric shape) in some cell. Then, spatial manipulations, represented by arrows indicating the direction of each move, are shown on the screen. The participant should select the stimulus's final position. The task has increasing difficultly, with a growing number of arrows and matrices (1 to 4). The score was the number of correct answers. Validity evidence was reported by Dias et al. $^{21}$.

In the FAS and Animals Verbal Fluency Test ${ }^{25}$, the individual must express the maximum possible number of words starting with $\mathrm{F}$ in a one-minute period of time. Then, the procedure is repeated with the letters A and S. Proper nouns were not allowed. This part measures phonemic fluency. In the second part, the individual must express the maximum number of animals, also in a one-minute period of time. This part assesses the semantic fluency. We used as scores the total number of correct words in phonemic and semantic categories. Validity evidence is in Dias et al. ${ }^{21}$.

We used the Brazilian version of the Childhood Executive Functioning Inventory (CHEXI) ${ }^{26}$ - translated, adapted, and validated in Brazilian children ${ }^{27}$. The CHEXI assesses EF in children. The instrument has 26 items, each of which is scored on a Likert scale. Items are grouped into four subscales: Working memory, Planning, Inhibitory control, and Self-regulation. In this study, the CHEXI was answered by participants' parents. The scores for each scale correspond to the level of difficulty that children have in that domain. We used the scores in each subscale and the total score.

The MTA-SNAP-IV ${ }^{28}$ is a questionnaire formulated from the DSM-IV, with the objective of assessing ADHD symptoms. The test consists of the description of the 18 symptoms of $\mathrm{ADHD}$, and for each one the child is given a score on a Likert scale of four levels of severity. In this study, the MTA-SNAP-IV was answered only by the parents of the participants. We reported total scores for inattention and hyperactivity indicators.

The Wechsler Intelligence Scale for Children $3^{\text {rd }}$ edition (WISC III), standardized for the Brazilian population by Figueiredo $^{29}$, aims to assess overall intellectual performance in children aged 6-16 years. The instrument consists of 13 
subtests, organized into Verbal and Performance scales. We used a shortened version with two subtests, vocabulary and block design, taken from the verbal scale and the performance scale, respectively. We added weighted scores in the two subtests and consulted the American modified table of Sattler ${ }^{30}$ to estimate IQ, which was used as a covariate in the inferential analyses.

The Intervention Program for Self-regulation and Executive Functions (PIAFEx) ${ }^{19}$ constitutes a set of activities designed to stimulate and promote the development of EF. It has 43 structured activities, divided into 10 basic modules and a supplementary module: Organization of materials/routine and time management; Organization of ideas, goal-setting and planning: Strategies for the day-to-day; Organization of ideas, goal-setting and planning: Stimulation activities; EF in Physical/Motor Activities; Communication and Conflict Management; Regulating emotions; Working with colleagues - Opportunities for exercising hetero- and self-regulation; Playing with the meanings of words; Talking about the activities; The Planned Play; and the Supplementary Module: Nina's Diary. For this study, the PIAFEx activities, originally developed for preschool and early elementary school, were adapted for older participants. The adaptation was made by raising the level of complexity of the activity (changing the stimuli and context of each activity) while maintaining its overall goal. Further details on the adaptation and implementation of PIAFEx activities can be obtained in the appendix or in the original work of Menezes ${ }^{31}$.

\section{Procedure}

The study was approved by the Ethics Committee. In the pretest period, in a private room at the university, participants were evaluated on each instrument. We established two orders of test application, so that in each evaluation the order of testing was reversed. The assessment was individual and in one session, with two intervals of ten to fifteen minutes. The entire procedure lasted from approximately two and a half to three hours. Parents were instructed to respond to the anamnesis interview, MTA-SNAP-IV and CHEXI.

During the intervention, the EG had hour-long meetings twice a week. Three subgroups were formed, two with three subjects and one with four subjects (two EG subjects did not remain until the end of the study). The activities were conducted for a period of 8 months. The CG did not have any type of intervention. After this period, the $8 \mathrm{EG}$ and $10 \mathrm{CG}$ participants were re-evaluated on each instrument, except the WISC III, according to the same procedure as before.

\section{Statistical analysis}

An ANCOVA was performed for each posttest measure to determine any group effects on the performances. Group assignment (CG or EG) was used as the independent variable, and previous performance (pretest measures), estimated IQ, and age were used as covariants. The level of confidence was set at 0.05 . Significant results are highlighted in bold and marginal trends $(0.05<\mathrm{p}<0.06)$ are in bold-italics.

\section{RESULTS}

Table 2 summarizes descriptive and inferential statistics. The EG performed better in relation to the CG even in pretesting, which is probably related to the fact that most EG participants were from private schools. Thus, controls for previous performance were needed. Significant effects of group assignment - even after controlling for previous performance, age, and IQ - were evident for scores in part 3 of the Stroop-Comp and for the AWM. Marginally significant effects were found for scores on part 2 and interference in the Stroop-Comp. EG participants responded more accurately to parts 2 and 3 - but especially 3 - in the Stroop-Comp, with gains over the $\mathrm{CG}$ in selective attention and inhibitory control. These findings also illustrate that the EG became skillful in maintaining and manipulating auditory information mentally, reaching better performance in the working memory measure compared to their CG peers. No effects were found on the other measures, despite tendencies among the EG toward better performance compared to the $\mathrm{CG}$ on some measures.

\section{DISCUSSION}

Despite the trend of better performance for the EG on some measures, effects do not reach statistical significance for most of the variables. It was possible to distinguish the groups only on the Stroop-Comp and AWM, for which the EG had better performance. In the Stroop-Comp, participants need to inhibit the automatic behavior of reading and select the appropriate stimulus in order to answer correctly. In this task, EG participants showed greater ability in dealing with interference, thus making fewer mistakes. In the AWM, each participant should remember and manipulate auditory information in his or her mind. Again, the EG seemed more able to perform the task. No other effects were found on flexibility, visual working memory, or in complex tests, such as the WCST and Verbal Fluency Test, or the CHEXI and MTA-SNAP-IV scales.

The lack of effects on scores in the complex tests could be understood as being caused by the tasks' demands. That is, these tests require the integrity and integration of diverse abilities $^{32}$ and maybe the intervention was not able to impact more complex performances, at least in our specific way of implementation. With regard to the CHEXI and MTA-SNAP$\mathrm{IV}$, both were answered by parents and maybe the intervention 
Table 2. Descriptive statistics (pretest) and ANCOVA-corrected descriptive statistics (posttest) for children's performances on each EF measurement with F- and p-values for the Experimental (EG) and Control (CG) Groups (controlling for pretest

performance, estimated IQ and age).

\begin{tabular}{|c|c|c|c|c|c|c|c|}
\hline \multirow[b]{2}{*}{ Variable } & \multirow[b]{2}{*}{ Group } & \multicolumn{2}{|c|}{ Pretest results } & \multicolumn{2}{|c|}{ Posttest results corrected after ANCOVA } & \multirow[b]{2}{*}{$\mathrm{F}$} & \multirow[b]{2}{*}{$\mathrm{p}$} \\
\hline & & M & SD & M & SE & & \\
\hline \multirow{2}{*}{ Stroop Score in part 2} & $C G$ & 0.97 & 0.03 & 0.99 & 0.01 & 4.66 & 0.06 \\
\hline & $E G$ & 0.96 & 0.05 & 1 & 0.01 & & \\
\hline \multirow[t]{2}{*}{ Stroop RT in part 2} & $C G$ & 0.60 & 0.12 & 0.64 & 0.03 & 0.04 & 0.84 \\
\hline & $E G$ & 0.62 & 0.14 & 0.65 & 0.03 & & \\
\hline \multirow[t]{2}{*}{ Stroop Score in part 3} & $C G$ & 0.79 & 0.22 & 0.86 & 0.03 & 6.79 & 0.03 \\
\hline & $E G$ & 0.85 & 0.09 & 0.98 & 0.03 & & \\
\hline \multirow[t]{2}{*}{ Stroop RT in part 3} & $C G$ & 1.18 & 0.25 & 1.19 & 0.05 & 0.36 & 0.56 \\
\hline & $E G$ & 1.42 & 0.68 & 1.14 & 0.05 & & \\
\hline \multirow[t]{2}{*}{ Stroop interference score } & $C G$ & -0.19 & 0.22 & -0.12 & 0.03 & 4.72 & 0.06 \\
\hline & $E G$ & -0.10 & 0.09 & -0.03 & 0.03 & & \\
\hline \multirow[t]{2}{*}{ Stroop interference RT } & $C G$ & 0.58 & 0.26 & 0.56 & 0.06 & 0.46 & 0.52 \\
\hline & $E G$ & 0.80 & 0.59 & 0.49 & 0.07 & & \\
\hline \multirow[t]{2}{*}{ CAT number of hits } & $C G$ & 62.80 & 21.10 & 76.08 & 3.81 & 0.00 & 0.98 \\
\hline & $E G$ & 79.25 & 14.05 & 76.28 & 4.42 & & \\
\hline \multirow{2}{*}{ TMT - sequences in part B } & $C G$ & 9.00 & 5.207 & 9.34 & 1.62 & 2.36 & 0.15 \\
\hline & $E G$ & 14.00 & 3.162 & 13.8 & 2.03 & & \\
\hline \multirow[t]{2}{*}{ WCST - hits } & $C G$ & 37.00 & 11.16 & 40.15 & 2.59 & 1.83 & 0.20 \\
\hline & $E G$ & 46.50 & 10.49 & 46.19 & 2.99 & & \\
\hline \multirow[t]{2}{*}{ WCST - errors } & $C G$ & 25.40 & 13.74 & 23.95 & 2.48 & 2.20 & 0.16 \\
\hline & $E G$ & 17.50 & 10.49 & 17.69 & 2.85 & & \\
\hline \multirow[t]{2}{*}{ WCST Perseverative responses } & $C G$ & 19.30 & 17.17 & 15.56 & 3.16 & 0.03 & 0.87 \\
\hline & $E G$ & 10.50 & 8.30 & 14.67 & 3.63 & & \\
\hline \multirow[t]{2}{*}{ WCST Perseverative errors } & $C G$ & 16.70 & 12.53 & 13.6 & 2.47 & 0.25 & 0.63 \\
\hline & $E G$ & 8.75 & 5.99 & 11.51 & 2.84 & & \\
\hline \multirow[t]{2}{*}{ WCST - completed categories } & $C G$ & 1.70 & 1.25 & 2.68 & 0.35 & 1.49 & 0.24 \\
\hline & $E G$ & 3.13 & 1.46 & 3.4 & 0.4 & & \\
\hline WCST - failure to maintain set & $C G$ & 1.70 & 2.00 & 0.3 & 0.3 & 1.34 & 0.27 \\
\hline & $E G$ & 0.75 & 1.16 & 0.88 & 0.34 & & \\
\hline AWM & $C G$ & 5.20 & 2.94 & 5.26 & 0.92 & 4.72 & 0.05 \\
\hline & $E G$ & 8.43 & 3.55 & 8.91 & 1.16 & & \\
\hline VWM & $C G$ & 5.30 & 3.92 & 7.15 & 0.71 & 0.93 & 0.35 \\
\hline & $E G$ & 6.71 & 3.64 & 8.36 & 0.88 & & \\
\hline Fluency FAS & $C G$ & 14.10 & 6.87 & 20.26 & 2.85 & 0.07 & 0.80 \\
\hline & $E G$ & 23.57 & 11.19 & 18.91 & 3.61 & & \\
\hline Fluency Animals & $C G$ & 10.60 & 4.06 & 10.86 & 1.41 & 0.35 & 0.57 \\
\hline & $E G$ & 11.71 & 3.45 & 12.34 & 1.75 & & \\
\hline CHEXI total score & $C G$ & 83.57 & 19.77 & 83.77 & 7.61 & 0.00 & 0.99 \\
\hline & $E G$ & 94.25 & 11.49 & 83.63 & 3.95 & & \\
\hline CHEXI working memory & $C G$ & 28.57 & 9.39 & 27.55 & 2.32 & 0.15 & 0.71 \\
\hline & $E G$ & 30.63 & 4.47 & 26.48 & 1.2 & & \\
\hline CHEXI planning & $C G$ & 13.00 & 3.32 & 14.42 & 2.27 & 0.72 & 0.42 \\
\hline & $E G$ & 14.75 & 1.75 & 12.08 & 1.18 & & \\
\hline CHEXI self-regulation & $C G$ & 16.14 & 5.76 & 19.56 & 1.31 & 0.93 & 0.37 \\
\hline & $E G$ & 20.63 & 3.38 & 18.04 & 0.69 & & \\
\hline CHEXI inhibitory control & $C G$ & 19.29 & 3.45 & 19.59 & 2.46 & 0.40 & 0.55 \\
\hline & $E G$ & 22.13 & 4.22 & 21.47 & 1.27 & & \\
\hline MTA-SNAP-IV inattention & $C G$ & 14.00 & 7.23 & 17.32 & 2.63 & 0.95 & 0.36 \\
\hline & $E G$ & 16.25 & 4.56 & 14.23 & 1.37 & & \\
\hline MTA-SNAP-IV hyperactivity & $C G$ & 11.29 & 7.16 & 14.14 & 2.52 & 0.29 & 0.61 \\
\hline & $E G$ & 14.38 & 6.09 & 12.51 & 1.32 & & \\
\hline
\end{tabular}

EF: Executive functions; IQ: Intelligence quotient; M: Mean; SD: Standard deviation; SE: Standard error; CG: Control group; EG: Experimental group; Stroop: Computerized Stroop Test; RT: Reaction time; CAT: Cancellation Attention Test; TMT: Trail Making Test; WCST: Wisconsin Card Sorting Test; AWM: Auditory Working Memory Test; VWM: Visual Working Memory Test; FAS: FAS Verbal Fluency Test; CHEXI: Childhood Executive Functioning Inventory; MTA-SNAP-IV: Swanson, Nolan, and Pelham-IV questionnaire used in the Multimodal Treatment Assessment Study. 
effects were not observed in other contexts. It is possible that a more intensive, frequent or longer intervention could have effects not only on simple tasks (such as the Stroop-Comp and AWM) but also on complex tasks and functional measures, reflecting greater generalization of the results. Additionally, despite evidence of the importance of $\mathrm{EF}$ in the neuropsychology of $\mathrm{ADHD}$, not all $\mathrm{ADHD}$ individuals have EF deficits ${ }^{6,7}$. It is possible that the lack of control of specific EF deficits in our sample (we do not have a healthy control group) may have contributed to the reduced effect of the intervention on our $\mathrm{ADHD}$ participants.

However, our findings of specific gains in inhibition and auditory working memory can have some importance, as the Willcutt et al.'s ${ }^{2}$ conclusion that ADHD is related to EF deficits, with stronger effects found for inhibitory control and working memory beyond vigilance and planning. Other intervention research has also reported effective results in the stimulation of selective attention, inhibitory control and/or working memory in subjects with $\mathrm{ADHD}^{14,33}$. However, research focused on more ecological interventions has not been done with subjects with $\mathrm{ADHD}$, which makes it difficult to compare the results we found here. Nevertheless, there is evidence that such interventions are effective in improving EF in samples of children with typical development $^{17,19}$.

Some questions remain for future investigation. Firstly, our intervention encourages individuals to think before performing a task. Perhaps intervention effects could be more evident using measures of time. In our study, time was only measured for the Stroop-Comp, thus providing a suggestion for further work. An interesting instrument that could be used is the Continuous Performance Test, which provides measures of omission and errors beside the reaction time. Secondly, if each EF skill develops in a specific way, reaching maturation in specific age ranges ${ }^{21}$, how is each skill subject to significant change at different times in their development? Perhaps different skills are more sensitive to intervention at different times of development. Again, future research needs to provide data that allows us to discuss this question.

Study limitations include the lack of activities with parents and/or teachers of the participants, which could contribute to the generalization of gains to other environments, such as home and school $^{17}$. Additionally, there was a small number of participants and the sample was heterogeneous in terms of school grade and age. It is suggested that future research should include larger samples, and groups with more homogeneous characteristics. It could be suitable to control for use of medication.

We agree that more controlled studies are desirable and necessary in experimental research. In line with this, we tried to control for some group differences by using IQ, age, and previous performance as covariates. However, our sample exemplifies the type of population that arrives at our clinics in the real world. Thus, despite its limitations, the study represents a start in this area. Research with the goal of providing cognitive interventions with ecological characteristics for a sample of subjects with $\mathrm{ADHD}$ is of great importance and sorely needed today. Nevertheless, such investigations are also quite scarce. The present study revealed inconclusive but promising results, showing that it is possible to promote inhibitory control and selective attention and auditory working memory in children and adolescents with ADHD.

\section{References}

1. American Psychiatric Association. Diagnostic and statistical manual of mental disorders. 5th ed. Arlington: American Psychiatric Association; 2013

2. Willcut EG, Doyle AE, Nigg JT, Faraone SV, Pennington BF. Validity of the executive function theory of attention-deficit/hyperactivity disorder: a meta-analytic review. Biol Psychiatry. 2005;57(11):1336-46. http://dx.doi.org/10.1016/j.biopsych.2005.02.006

3. Diamond A. Executive functions. Annu Rev Psychol. 2013;64(1):13568. http://dx.doi.org/10.1146/annurev-psych-113011-143750

4. Castellanos FX, Sonuga-Barke EJS, Milham MP, Tannock, R. Characterizing cognition in ADHD: beyond executive dysfunction. Trends Cogn Sci. 2006;10(3):117-23. http://dx.doi.org/10.1016/j.tics.2006.01. 011

5. Nigg JT. Is ADHD a disinhibitory disorder? Psychol Bull. 2001;127 (5):571-98. http://dx.doi.org/10.1037/0033-2909.127.5.571

6. Lambek R, Tannock R, Dalsgaard S, Trillingsgaard A, Damm D, Thomsen $\mathrm{PH}$. ValidAting neuropsychological subtypes of ADHD: how do children with and without an executive function deficit differ? J Child Psychol Psychiatry. 2010;51(8):895-904. http://dx.doi.org/10.1111/ j.1469-7610.2010.02248.x
Saboya E, Coutinho G, Segenreich D, Ayrão V, Mattos P. Lack of executive function déficits among adult $A D H D$ individuals from a Brazilian clinical sample. Dementia Neuropsychol. 2009;3(1):34-7.

8. Nigg JT, Willcutt E, Doyle AE, Sonuga-Barke EJS. Causal heterogeneity in attention deficit/hyperactivity disorder: do we need neuropsychologically impaired subtypes? Biol Psychiatry. 2005;57(11):122430. http://dx.doi.org/10.1016/j.biopsych.2004.08.025

9. Wasserstein J, Lynn A. Metacognitive remediation in adult ADHD. Treating executive function deficits via executive functions. Ann N Y Acad Sci. 2001;931(1):376-84. http://dx.doi.org/10.1111/j.1749-6632. 2001.tb05791.x

10. Polanczyk G, Casella E, Miguel E, Reed U. Attention deficit disorder/ hyperactivity: a scientific overview. Clinics (São Paulo). 2012;67(10):1125-6. http://dx.doi.org/10.6061/clinics/2012(10)01

11. Murphy K, Ratey N, Maynard S, Sussman S, Wright SD. Coaching for ADHD. J Atten Disord. 2010;13(5):546-52. http://dx.doi.org/10.1177/ 1087054709344186

12. Knight LA, Rooney M, Chronis-Tuscano A. Psychosocial treatments for attention deficit/ hyperactivity disorder. Curr Psychiatry Rep. 2008;10(5):412-8. http://dx.doi.org/10.1007/s11920-008-0066-6 
13. Pelham Jr WE, Fabiano GA. Evidence-based psychosocial treatments for attention-deficit/hyperactivity disorder. J Clin Child Adolesc Psychol. 2008;37(1):184-214. http://dx.doi.org/10.1080/15374410701818681

14. Tamm L, Hughes C, Ames L, Pickerin J, Silver CH, Stavinoha P et al. Attention training for school-aged children with ADHD: results of an open trial. J Atten Disord. 2010;14(1):86-94. http://dx.doi.org/10. $1177 / 1087054709347446$

15. Reeves G, Anthony B. Multimodal treatments versus pharmacotherapy alone in children with psychiatric disorders: implications of access, effectiveness, and contextual treatment. Pediatr Drugs. 2009;11(3):165-9. http://dx.doi.org/10.2165/00148581-200911030-00002

16. Shipstead Z, Hicks KL, Engle RW. Cogmed working memory training: Does the evidence support the claims? J Appl Res Mem Cogn. 2012;1 (3):185-93. http://dx.doi.org/10.1016/j.jarmac.2012.06.003

17. Diamond A, Barnett WS, Thomas J, Munro S. Preschool program improves cognitive control. Science. 2007;318(5855):1387-8. http:// dx.doi.org/10.1126/science.1151148

18. Dawson P, Guare R. Executive skills in children and adolescents: a practical guide to assessment and intervention. New York: The Guilford; 2010.

19. Dias NM, Seabra AG. Programa de Intervenção sobre a Autorregulação e Funções Executivas - PIAFEx. Sao Paulo: Memnon; 2013.

20. Assef ECS, Capovilla AGS, Capovilla FC. Computerized stroop test to assess selective attention in children with attention deficit hyperactivity disorder. Span J Psychol. 2007;10(1):33-40. http://dx.doi.org/ 10.1017/S1138741600006296

21. Dias NM, Menezes A, Seabra AG. Age differences in executive functions within a sample of Brazilian children and adolescents. Span J Psychol 2013;16:E9. http://dx.doi.org/10.1017/sjp.2013.12

22. Seabra AG, Dias NM. Avaliação neuropsicológica cognitiva: atenção e funções executivas. Sao Paulo: Memnon, 2012. vol.1.

23. Heaton RK, Chelune GJ, Talley JL, Kay GG, Curtiss G. Manual do Teste Wisconsin de Classificação de Cartas. Adaptação e padronização brasileira: Cunha JA, Trentini C, Argimon I, Oliveira M, Werlang B, Prieb R. Sao Paulo: Casa do Psicólogo; 2005.
24. Primi R. [Computadorized battery of cognitive skills]. Software. Itatiba: LabAPE; 2002. Portuguese.

25. Seabra AG. [FAS VERBAL FLUENCY TEST] [Software]. Sao Paulo: Universidade Presbiteriana Mackenzie; [2008].

26. Thorell LB, Nyberg L. The childhood executive functioning inventory (CHEXI): a new rating instrument for parents and teachers. Dev Neuropsychol. 2008;33(4):536-52. http://dx.doi.org/10.1080/87565640802101516

27. Trevisan BT, Dias NM, Menezes A, Seabra AG. The Brazilian version of the Childhood Executive Functioning Inventory (CHEXI) for evaluation of children with ADHD. In: Eunethydis 2nd Internacional ADHD Conference; May 2012; Barcelona, Spain: Eunethydis; 2012. p. 176-176.

28. Mattos P, Serra-Pinheiro MA, Rohde LA, Pinto D. Apresentação de uma versão em português para uso no Brasil do instrumento MTASNAP-IV de avaliação de sintomas de transtorno do déficit de atenção/hiperatividade e sintomas de transtorno desafiador e de oposição. Rev Psiquiatr Rio Gs Sul. 2006;28(3):290-7. http://dx.doi. org/10.1590/S0101-81082006000300008

29. Figueiredo VLM. WISC III: escala de inteligência Wechsler para crianças. 3a ed. Sao Paulo: Casa do Psicólogo; 2001.

30. Strauss E, Sherman EMS, Spreen OA. Compendium of Neuropsychological Tests: Administration, norms and commentary. New York: Oxford University Press; 2006.

31. Menezes A. Adaptação e implementação do Programa de Intervenção Precoce sobre o Funcionamento Executivo para crianças e adolescentes com TDAH [Doctor's thesis]. São Paulo: Universidade Presbiteriana Mackenzie; 2013.

32. Dias NM, Seabra AG. The FAS Fluency Test in Brazilian children and teenagers: Executive demands and the effects of age and gender. Arq Neuropsiquiatr. 2014;72(1):55-62. http://dx.doi.org/10.1590/0004282X20130213

33. Klingberg $T$, Fernell $E$, Olesen PJ, Johnson M, Gustafsson P, Dahlström $\mathrm{K}$ et al. Computerized training of working memory in children with ADHD - A randomized, controlled trial. J Am Acad Child Adolesc Psychiatry. 2005;44(2):177-86. http://dx.doi.org/10.1097/ 00004583-200502000-00010 


\section{APPENDIX}

As not all activities proposed in the PIAFEx are appropriate to the clinical context and with older participants, only some of them have been selected for this study. Among those selected, some were adapted to allow for work with older children and in a different context. Table A1 presents the description, use, and adaptation of all PIAFEx activities (as in Dias and Seabra ${ }^{19}$ ).

Activities from Modules 1 and 2 are strategies to support the organization, planning, and establishment of goals. Some were used daily (Daily schedule and Calendar); others were used to support performance in other activities when needed. Activities from Modules 3 to 8 were selected randomly during the week, while trying to not repeat activities from the same module in following sessions. Two or three activities were conducted per day. The activity from Module 9 was conducted every day combined with or after other activities. Module 10 and the supplementary module were conducted once a week.

Table A1. Details of selected activities and adjustments made from PIAFEX.

\begin{tabular}{|c|c|c|c|c|}
\hline PIAFEx Modules & Activities & $\begin{array}{l}\text { Activity } \\
\text { name }\end{array}$ & $\begin{array}{l}\text { Description of the } \\
\text { original activity }\end{array}$ & Adaptation \\
\hline \multirow{4}{*}{$\begin{array}{l}\text { M1 - } \\
\text { Organization } \\
\text { of } \\
\text { materials/ } \\
\text { routine } \\
\text { and time } \\
\text { management }\end{array}$} & 1 & $\begin{array}{c}\text { Daily } \\
\text { schedule }\end{array}$ & $\begin{array}{l}\text { In this task, the mediator sets the day's } \\
\text { tasks in the form of routine. With every } \\
\text { task performed, the routine is updated. }\end{array}$ & $\begin{array}{l}\text { Used with no adaptation } \\
\text { - used to organize } \\
\text { the daily activities. }\end{array}$ \\
\hline & 2 & - & Not used & - \\
\hline & 3 & - & Not used & - \\
\hline & 4 & $\begin{array}{l}\text { Time } \\
\text { management }\end{array}$ & $\begin{array}{l}\text { The activity proposes visual aids to help } \\
\text { participants deal with the notion of time } \\
\text { and organize their behavior according } \\
\text { to the time available for each task. }\end{array}$ & $\begin{array}{l}\text { Used with no adaptation } \\
\text { - used to support time } \\
\text { management during activities. }\end{array}$ \\
\hline \multirow[t]{5}{*}{$\begin{array}{l}\text { M2 - } \\
\text { Organization } \\
\text { of ideas, } \\
\text { goal-setting } \\
\text { and planning: } \\
\text { Strategies } \\
\text { for the } \\
\text { day-to-day }\end{array}$} & 1 & Calendar & $\begin{array}{l}\text { A monthly calendar is used to mark } \\
\text { commitments and important dates to } \\
\text { help in organization and planning. }\end{array}$ & $\begin{array}{l}\text { Used with no adaptation. Calendar } \\
\text { was made on the first day } \\
\text { of each month. Children were } \\
\text { encouraged to mark appointments, } \\
\text { tests, and important dates. } \\
\text { Calendar was consulted } \\
\text { every session. }\end{array}$ \\
\hline & 2 & $\begin{array}{l}\text { Graphic } \\
\text { organizers }\end{array}$ & $\begin{array}{l}\text { A tool to help children to deal with } \\
\text { multi-step tasks and objectives. }\end{array}$ & $\begin{array}{l}\text { Used with no adaptation } \\
\text { - used to help to plan } \\
\text { complex tasks. }\end{array}$ \\
\hline & 3 & Check-lists & $\begin{array}{l}\text { A list to help checking, planning, } \\
\text { or organization of materials. }\end{array}$ & $\begin{array}{l}\text { Used with no adaptation } \\
\text { - used to help remember } \\
\text { things to do or materials } \\
\text { needed for some activity. }\end{array}$ \\
\hline & 4 & - & Not used & - \\
\hline & 5 & - & Not used & - \\
\hline \multirow{5}{*}{$\begin{array}{l}\text { M3 - Organization } \\
\text { of ideas, goal- } \\
\text { setting and } \\
\text { planning: } \\
\text { Stimulation } \\
\text { activities }\end{array}$} & 1 & - & Not used & - \\
\hline & 2 & - & Not used & - \\
\hline & 3 & $\begin{array}{l}\text { Main idea } \\
\text { x Details }\end{array}$ & $\begin{array}{l}\text { A card with a set of pictures is presented. } \\
\text { Children are encouraged to think about } \\
\text { the general idea and its specificities. }\end{array}$ & $\begin{array}{l}\text { Used with no adaptation } \\
\text { - used to discuss different perspectives. } \\
\text { Discussion could be in depth } \\
\text { in relation to the activity } \\
\text { conducted with preschoolers. }\end{array}$ \\
\hline & 4 & $\begin{array}{l}\text { Linking } \\
\text { figures } 1\end{array}$ & $\begin{array}{c}\text { Children should link some pictures according } \\
\text { to specific criteria. After, the activity is } \\
\text { repeated, but with new criteria. }\end{array}$ & $\begin{array}{c}\text { Used with adaptation - activities } \\
4 \text { and } 5 \text { were combined. } \\
\text { Discussion was encouraged }\end{array}$ \\
\hline & 5 & $\begin{array}{l}\text { Linking } \\
\text { figures } 2\end{array}$ & $\begin{array}{l}\text { Children should link some pictures according } \\
\text { to specific criteria. After, the activity is } \\
\text { repeated, but children should } \\
\text { alternate between criteria. }\end{array}$ & after the activity. \\
\hline
\end{tabular}

Continue 


\begin{tabular}{|c|c|c|c|c|}
\hline $\begin{array}{l}\text { M4 - } \\
\text { EF in }\end{array}$ & 1 & - & $\begin{array}{l}\text { Not used (space limitations } \\
\text { in the clinical context) }\end{array}$ & - \\
\hline \multirow{13}{*}{$\begin{array}{l}\text { Physical/ } \\
\text { Motor } \\
\text { Activities }\end{array}$} & 2 & Simon says & A child or the mediator plays "Simon." & Used with no adaptation \\
\hline & & & $\begin{array}{l}\text { Children need to make movements } \\
\text { according to Simon's orders. }\end{array}$ & \\
\hline & 3 & - & $\begin{array}{l}\text { Not used (space limitations } \\
\text { in the clinical context) }\end{array}$ & - \\
\hline & 4 & - & $\begin{array}{l}\text { Not used (space limitations } \\
\text { in the clinical context) }\end{array}$ & - \\
\hline & 5 & - & $\begin{array}{l}\text { Not used (space limitations } \\
\text { in the clinical context) }\end{array}$ & - \\
\hline & 6 & - & $\begin{array}{l}\text { Not used (space limitations } \\
\text { in the clinical context) }\end{array}$ & - \\
\hline & 7 & - & $\begin{array}{l}\text { Not used (space limitations } \\
\text { in the clinical context) }\end{array}$ & - \\
\hline & 8 & - & $\begin{array}{l}\text { Not used (space limitations } \\
\text { in the clinical context) }\end{array}$ & - \\
\hline & 9 & - & $\begin{array}{l}\text { Not used (space limitations } \\
\text { in the clinical context) }\end{array}$ & - \\
\hline & 10 & - & $\begin{array}{l}\text { Not used (space limitations } \\
\text { in the clinical context) }\end{array}$ & - \\
\hline & 11 & Hit cards 1 & $\begin{array}{l}\text { This is a card game. There } \\
\text { is a target stimulus } \\
\text { (for example, the picture of a cat) and each } \\
\text { child receives a number of cards. One at a } \\
\text { time, children must discard a card on } \\
\text { the table. If the discarded card is the } \\
\text { target stimulus, all must hit the deck. } \\
\text { The latest to hit takes all of the cards. } \\
\text { The child who discards } \\
\text { their hand first is the winner. }\end{array}$ & $\begin{array}{l}\text { Used with adaptations } \\
\text { - the rules were the same, } \\
\text { but cards contained distractor } \\
\text { stimuli to increase the } \\
\text { complexity of the task } \\
\text { (e.g., while in the } \\
\text { original task children } \\
\text { should hit if the card of } \\
\text { the cat is shown, in the } \\
\text { adapted task, they should }\end{array}$ \\
\hline & 12 & Hit cards 2 & $\begin{array}{l}\text { The same as Hit cards 1, but } \\
\text { stimuli are letters and numbers. }\end{array}$ & $\begin{array}{l}\text { hit the card with a white } \\
\text { cat only if the cat has a }\end{array}$ \\
\hline & 13 & Hit cards 3 & $\begin{array}{c}\text { The same as Hit cards } 1 \text {, but there is a } \\
\text { new rule. Some cards are red in the } \\
\text { back. Even if the card has the target } \\
\text { stimulus, children cannot hit the red cards. }\end{array}$ & red tie around its neck). \\
\hline \multirow[t]{3}{*}{$\begin{array}{l}\text { M5 - } \\
\text { Communication } \\
\text { and Conflict } \\
\text { Management }\end{array}$} & 1 & $\begin{array}{l}\text { Time for } \\
\text { dialogue }\end{array}$ & $\begin{array}{c}\text { This task is used at the end of the } \\
\text { week to discuss events and problems } \\
\text { in the classroom and to discuss and } \\
\text { model more adaptive ways to } \\
\text { deal with and solve problems with peers. }\end{array}$ & $\begin{array}{l}\text { Used with adaptation } \\
\text { - children could discuss personal } \\
\text { events during the week. Adaptive } \\
\text { ways of solving problems were } \\
\text { discussed and modeled. }\end{array}$ \\
\hline & 2 & - & Not used & - \\
\hline & 3 & - & Not used & - \\
\hline \multirow[t]{3}{*}{$\begin{array}{l}\text { M6 - } \\
\text { Regulating } \\
\text { emotions }\end{array}$} & 1 & $\begin{array}{l}\text { Dealing with } \\
\text { emotions }\end{array}$ & $\begin{array}{l}\text { This is a four-step technique to help } \\
\text { children to recognize and deal with } \\
\text { their emotions. The steps are: } \\
\text { 1) recognize your feeling; 2) Stop and } \\
\text { think; 3) reflect and breathe } \\
\text { deeply three times; } \\
\text { 4) Now, think of a solution. }\end{array}$ & $\begin{array}{l}\text { Used with no adaptation. } \\
\text { Steps to recognize and } \\
\text { control emotions were } \\
\text { modeled and simulated. }\end{array}$ \\
\hline & 2 & - & Not used & - \\
\hline & 3 & - & Not used & - \\
\hline
\end{tabular}

Continue 
M7 - Working

with

colleagues

- Opportunities

for exercising

hetero- and

self-regulation Reading with
pictures

$\begin{array}{cc}1 & \begin{array}{c}\text { Reading with } \\ \text { pictures }\end{array} \\ & \\ & \\ 2 & \\ & \\ & \\ & \\ 3 & \\ 4 & - \\ 5 & - \\ 6 & \text { Blocks design }\end{array}$

NEW Planning projects

M8 - Playing

with

the meanings

of

words

M9 -

Talking about the activities

\section{M10 - The \\ Play}

Activity is conducted with peers.

Children have different roles and should coordinate them to achieve a common goal. One child should tell a story based on pictures. The other must maintain

his/ her role and just listen to the story. The structure is similar to the previous activity. Children take the books home and parents read for them. The next day, children should tell the story to their colleague.

Children assume roles again.

\section{Not used \\ Not used \\ Not used}

Children assume roles (the engineer or the builder). The engineer should plan

the construction, and the builder must set up blocks according to the plan.
This task uses ambiguous words to show children that a word

can have more than one meaning. This task uses ambiguous phrases and folk sayings.

This task uses questions to stimulate children's thinking about how they perform tasks. It promotes metacognition.

\section{It is an imaginative play that can be conducted in groups. Children should plan}

the play before its implementation. They should think about roles, scenarios, and materials. After, they must act according to the initial plan.

This is a narrative with 10 chapters. In the story, the protagonist Nina faces situations in which she needs to learn how to control her emotions and behavior, plan and organize, and solve problems. After each chapter, there are activities to help children exercise the strategies modeled by Nina.
Used with adaptation

- instead of using pictures, children can read the story to their colleagues.

Comic books can also be used.

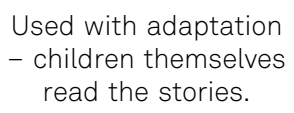
read the stories.

Used with no adaptation - the complexity of projects were enhanced in relation to the work with young children; the task was the same.

New activity designed from the objectives and structure of Module 7. In Planning projects, children should think broadly about building a project that has several steps to completion (e.g., building a game).

Used with no adaptation - discussion/reflection could be more profound in relation to work with young children.

Used with adaptations - this activity was conducted in the context of other tasks, for example during games as puzzles or a memory game. Children were encouraged to think about strategies used and evaluate their effectiveness.

Used with some adaptations - the objective and structure were the same. More complex plans (with more details) and scenarios (e.g., interchange in a different country) were stimulated.

Used with some adaptations - children themselves read the chapters during the session. Afterwards, all participated in the discussion and activities. The discussion could be enhanced in relation to the activity conducted with preschoolers. 